\title{
Pneumococcal Neuraminidase
}

\author{
L. T. LEE AND C. HOWE \\ Department of Microbiology, College of Physicians and Surgeons, Columbia University, New York, New York
}

Received for publication 8 December 1965

\begin{abstract}
LeE, L. T. (Columbia University, New York, N.Y.), AND C. HowE. Pneumoccal neuraminidase. J. Bacteriol. 91:1418-1426. 1966.-The elaboration of neuraminidase by pneumococci grown under optimal conditions in liquid medium was studied in relation to the bacterial growth cycle. The enzyme was found free in the culture medium in increasing concentration throughout most of the logarithmic phase of growth, at the end of which enzyme concentration had reached a maximum. Only a small fraction of the total neuraminidase was cell-associated at any time. It appears, therefore, that pneumococcal neuraminidase is actively secreted by dividing cells and does not accumulate solely as a result of cellular autolysis. Neuraminidase in cell-free extracts (types I, III, VII, and XIV) was neutralized both by homotypic and by heterotypic antibody, thus demonstrating it to be a group antigen. The enzyme was separable in agar gel electrophoresis from other protein and polysaccharide pneumococcal antigens. Limited immunochemical data suggest that pneumococcal neuraminidase may be of relatively low molecular weight.
\end{abstract}

When cultivated in liquid medium under optimal conditions, the pneumococcal cell undergoes autolysis owing to the action of its own enzymes. Such active disintegration of cells, occurring even before the end of the exponential phase of growth, accounts in large measure for the presence of polysaccharide components and enzymes free in the culture medium. Neuraminidase, regularly present in such autolysates, may also be secreted into the medium by the actively dividing cells relatively early in the growth cycle, before much autolysis has occurred. To explore this possibility, experiments were undertaken to relate the appearance and accumulation of neuraminidase to the growth of pneumococci in liquid medium and subsequently to characterize the enzyme immunologically and electrophoretically. The results form the basis of this report.

\section{Materials AND Methods}

Cultures. For the production of bulk quantities, pneumococci were grown in Neopeptone-beef heart infusion broth (both from Difco), each liter of which was supplemented with $1.5 \mathrm{ml}$ of $20 \%$ glucose and $15 \mathrm{ml}$ of $0.5 \mathrm{M} \mathrm{K}_{2} \mathrm{HPO}_{4}$. The same medium was used for growth curve experiments described below. Cultures were maintained at $37 \mathrm{C}$ for $16 \mathrm{hr}$, after which $6 \mathrm{ml}$ of $20 \%$ glucose and $15 \mathrm{ml}$ of $0.5 \mathrm{M} \mathrm{K}_{2} \mathrm{HPO}_{4}$ were added to each liter. For the conversion of pneumococcus type XIV from the smooth to the rough form, organisms were put through two 18 -hr passages of the same broth containing type XIV antiserum. Organisms cultured in this manner failed to show cap- sular swelling with anti-SXIV, and type-specific polysaccharide was absent from sonic-treated cell material examined by immunoelectrophoretic analysis.

Antisera. Horse antisera to pneumococcus types I, III, and VII were supplied by the New York City Department of Health. Type XIV rabbit antiserum (no. 154) was kindly supplied by Lederle Laboratories, Pearl River, N.Y. Rabbits were immunized with pneumococcal extracellular antigens (see below) by three weekly injections, into the footpads, of $2 \mathrm{mg}$ of protein in complete Freund adjuvant. Animals were bled 7 to $\mathbf{1 0}$ days after the last injection. Rabbit antisera were concentrated by precipitation of globulins at $40 \%$ of saturation with sodium sulfate.

Analytical procedures. Electrophoretic and immunoelectrophoretic analyses in agar gel were performed as described by Grabar and Burtin (1). Lyophilized material was dissolved at known concentration in buffer just before being applied to the agar. Separations were carried out at room temperature in $0.05 \mathrm{~m}$ Veronal buffer $(p \mathrm{H} \mathrm{8.2)}$ at $100 \mathrm{v}$ and a current of 5 to 10 ma per slide $(7.7$ by 5.2 or $2.6 \mathrm{~cm}$ ). Electrophoretic and immunoelectrophoretic preparations were stained for polysaccharide by the procedure of Uriel and Grabar (11), and for proteins with Ponceau red. Specific precipitates were analyzed for nitrogen after digestion by the microninhydrin procedure $(4,10)$. The preparation and properties of Collocalia mucoid, used as substrate for neuraminidase assays, have been described elsewhere (2). $N$-acetylneuraminic acid (NANA) was determined by the method of Warren (12), with crystalline NANA as standard. Neuraminidase activity was estimated by measuring the rate at which NANA was liberated from Collocalia 
mucoid at $37 \mathrm{C}$ in $0.15 \mathrm{M}$ phosphate buffer at optimal $p H$ (6.0), and was expressed as a percentage of the total NANA obtainable by hydrolysis of a standard sample at $80 \mathrm{C}$ for $20 \mathrm{~min}$ in $0.1 \mathrm{~N} \mathrm{H}_{2} \mathrm{SO}_{4}$.

Enzyme neutralization tests. Collocalia mucoid, dissolved in $0.15 \mathrm{M} \mathrm{NaCl}$ buffered to $p \mathrm{H} 6.0$ with 0.015 M phosphate, was used as substrate. Cell-free extracts, or extracellular antigen (ECA), dissolved in phosphate-buffered saline, were used at a concentration such that 90 to $100 \%$ of the total bound NANA in 400 $\mu \mathrm{g}$ of Collocalia mucoid was liberated in 14 to $16 \mathrm{hr}$. To serial dilutions of antiserum in a volume of 0.5 $\mathrm{ml}, 0.2 \mathrm{ml}$ of enzyme was added. After mixing, the tubes were allowed to stand at room temperature for $30 \mathrm{~min}$. A $400-\mu \mathrm{g}$ sample of Collocalia mucoid in 0.2 $\mathrm{ml}$ was then added to all tubes, which, after mixing, were incubated at $37 \mathrm{C}$ for 14 to $16 \mathrm{hr}$. After incubation, duplicate samples of $0.2 \mathrm{ml}$ were taken from each reaction mixture and analyzed for free NANA. As controls, mixtures of antiserum dilutions and enzyme without Collocalia mucoid, and mixtures of enzyme and substrate without serum, were similarly incubated and analyzed for free NANA.

Cell-free extracts. Organisms from 12- to 16-hr cultures of pneumococcus types I, III, VII, and XIV were harvested by centrifugation at $35,000 \times g$ for 1 $\mathrm{hr}$. Sedimented pellets were washed twice in saline, followed by centrifugation at $1,000 \times g$ at $4 \mathrm{C}$ after each wasning. The organisms were then resuspended in a volume of demineralized water nine times that of the packed cells, and subjected to sonic disruption for $30 \mathrm{~min}$. The resulting sonic-treated material was centrifuged at $80,000 \times g$ for $90 \mathrm{~min}$, and the supernatant fluid was removed and dialyzed against demineralized water for $16 \mathrm{hr}$. This was followed by filtration through a Millipore filter (porosity of $0.45 \mu$ ) for further clarification before lyophilization.

\section{RESULTS}

Neuraminidase in relation to the growth cycle. To determine the relationship of neuraminidase to the growth cycle, 12-hr growth curves were done on pneumococcus types I and XIV. An 8-hr culture was centrifuged at $4 \mathrm{C}$ for $15 \mathrm{~min}$, and the supernatant fluid was decanted. The sedimented organisms were washed once in sterile saline and resuspended in $5 \mathrm{ml}$ of glucose-phosphate medium. A 1-ml amount of this suspension was inoculated into $100 \mathrm{ml}$ of prewarmed medium. The inoculated medium, in 10-ml quantities, was immediately dispensed to centrifuge tubes, which were incubated at $37 \mathrm{C}$. At successive 2-hr intervals after inoculation, one $10-\mathrm{ml}$ sample was taken for enzyme analysis and for viable cell count, with the use of the standard plate dilution technique. A 2-ml amount of the culture was frozen, and the remaining $8 \mathrm{ml}$ was centrifuged immediately at $4 \mathrm{C}$ for $15 \mathrm{~min}$. The supernatant fluid was decanted and frozen, and the sedimented cells, after being washed once in saline, were resuspended in $2 \mathrm{ml}$ of saline and frozen.
All frozen samples were then stored until they could be assayed together for neuraminidase activity, prior to which each sample of whole culture and washed cell suspension $(2 \mathrm{ml})$ was subjected to sonic disruption. The concentrations of intracellular and extracellular neuraminidase in cultures of pneumococcus $I$ and XIV are charted in Fig. 1 and 2, respectively, in relation to the growth curve of each organism and to the total neuraminidase found at each time interval. With type XIV, enzyme activity could be detected as early as 2 to $4 \mathrm{hr}$ after inoculation of the culture. More than half of the total enzyme in the whole culture at each time point, even in the early phase of growth, was found free in the suspending medium. Enzyme remaining in the cells was never more than a small fraction of the total. With type I, enzyme activity was first detected in the whole cultures and supernatant fluid $6 \mathrm{hr}$ after inoculation. With both types I and XIV, the amount of activity measured in the cell-free culture supernatant fluids after $6 \mathrm{hr}$ accounted for most of the enzyme present, relatively little being found in the washed cells at any point in the growth curve.

After being assayed for neuraminidase activity, culture supernatant fluids at each point on the curve were dialyzed and lyophilized. On im-

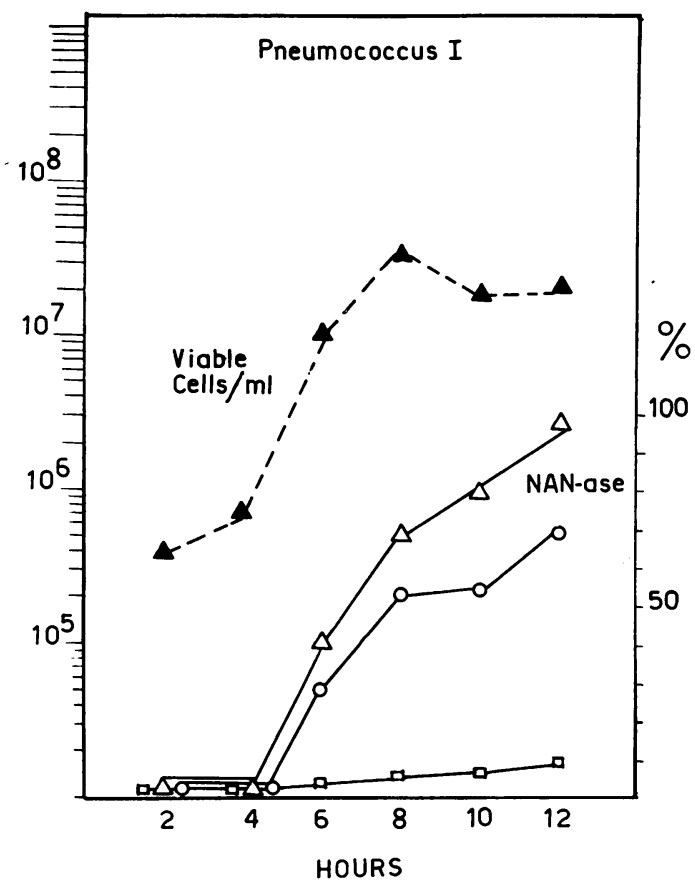

FIG. 1. Growth cycle of pneumococcus type I. Neuraminidase activity in culture supernatant fluid $(O)$, in whole culture $(\triangle)$, and in culture sediment $(\square)$. 


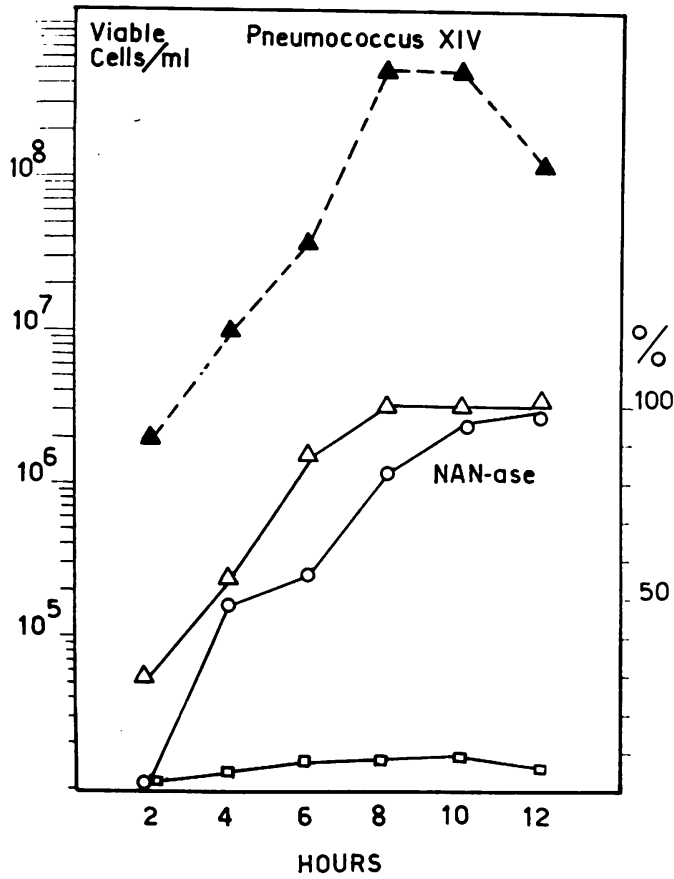

Fig. 2. Growth cycle of pneumococcus type XIV. Neuraminidase activity in culture supernatant fluid $(O)$, in whole culture $(\triangle)$, and in culture sediment $(\square)$.

munoelectrophoretic analysis with homologous antibody, no visible lines of precipitate were detected in samples taken before $8 \mathrm{hr}$. Capsular polysaccharide and $\mathbf{C}$ substance were, however, identified in the sample taken at $8 \mathrm{hr}$ and in all those subsequently analyzed.

Electrophoretic mobility of neuraminidase in agar gel. To determine the mobility of neuraminidase in relation to other cell components, a cellfree extract was prepared from a rough strain of pneumococcus (originally type XIV), and cells were harvested $12 \mathrm{hr}$ after inoculation. Under these conditions, the enzyme could be expected to constitute but a small fraction of the total cellular antigenic mass, since, as already demonstrated, most of the enzyme at this late point in the growth cycle was to be found in the culture supernatant fluid. However, sufficient enzyme was regularly present in amounts adequate for estimation of electrophoretic motility in relation to other cellular constituents. Three pairs of duplicate samples of cell-free extract were subjected to electrophoresis for periods of increasing length. At each time interval, one of each pair of samples was developed with anti-XIV. The strip of agar containing the second sample was cut into sections of equal length at right angles to the path of migration. The slices were then individually incubated in substrate for suitable periods at $37 \mathrm{C}$, and the extract was analyzed for NANA. The results (Fig. 3) indicate that the neuraminidase is slower in mobility than most of the other cell constituents, from which it can be distinctly separated by prolonged electrophoresis $(8 \mathrm{hr})$. Moreover, no precipitation line was found which corresponded with the area of enzyme activity in the immunoelectrophoretic pattern of cell-free extract developed with type XIV antiserum.

Analysis of antisera to "purified" culture supernatant fluid. Protein was precipitated with ammonium sulfate at 0.75 saturation from the supernatant fluid of a 12-hr culture of a rough strain of pneumococcus (originally type XIV). After dialysis, the material was passed through Sephadex G100 and developed with $0.1 \mathrm{M}$ tris(hydroxymethyl)aminomethane buffer $(p \mathrm{H}$ 7.5) containing $0.2 \mathrm{M}$ calcium acetate (6). Thirty fractions of $5 \mathrm{ml}$ each were collected from the column, and each of these was measured for neuraminidase activity and for protein absorption at $280 \mathrm{~m} \mu$. The peak of enzyme activity was found from the 10th to 17th tube, and corresponded with the protein peak. Samples showing the highest enzyme activity were pooled, dialyzed for $24 \mathrm{hr}$ against demineralized water, and lyophilized. This partially purified preparation, containing neuraminidase and hereinafter referred to as "extracellular antigen(s)" (ECA), was used for immunization of three rabbits, as described above in Materials and Methods. None of the antisera so obtained neutralized neuraminidase activity when assayed by the tube method, as also described earlier. Immunoelectrophoretic analysis of ECA, however, developed with each of the three rabbit antisera to ECA, showed two precipitating antigens to be present just ahead of the starting well, and corresponding in position to the area of neuraminidase activity. This is shown for one of the antisera (606) in the lower photograph in Fig. 5. Longer electrophoretic separation $(5 \mathrm{hr})$ resulted in the removal of the innermost precipitating line to a point projecting well beyond the area of enzyme activity, whereas the second and slower antigen still precipitated in relation to neuraminidase activity (Fig. 4). These observations suggested that the slower component might be neuraminidase, which precipitated with, but, as already noted, was not neutralized by anti-ECA. This possibility was further suggested by the results of "direct immunoelectrophoretic analysis" (13). ECA was placed in two elongated reservoirs on the same slide and subjected to electrophoresis for $1.5 \mathrm{hr}$. Antiserum (606) was then placed in a 


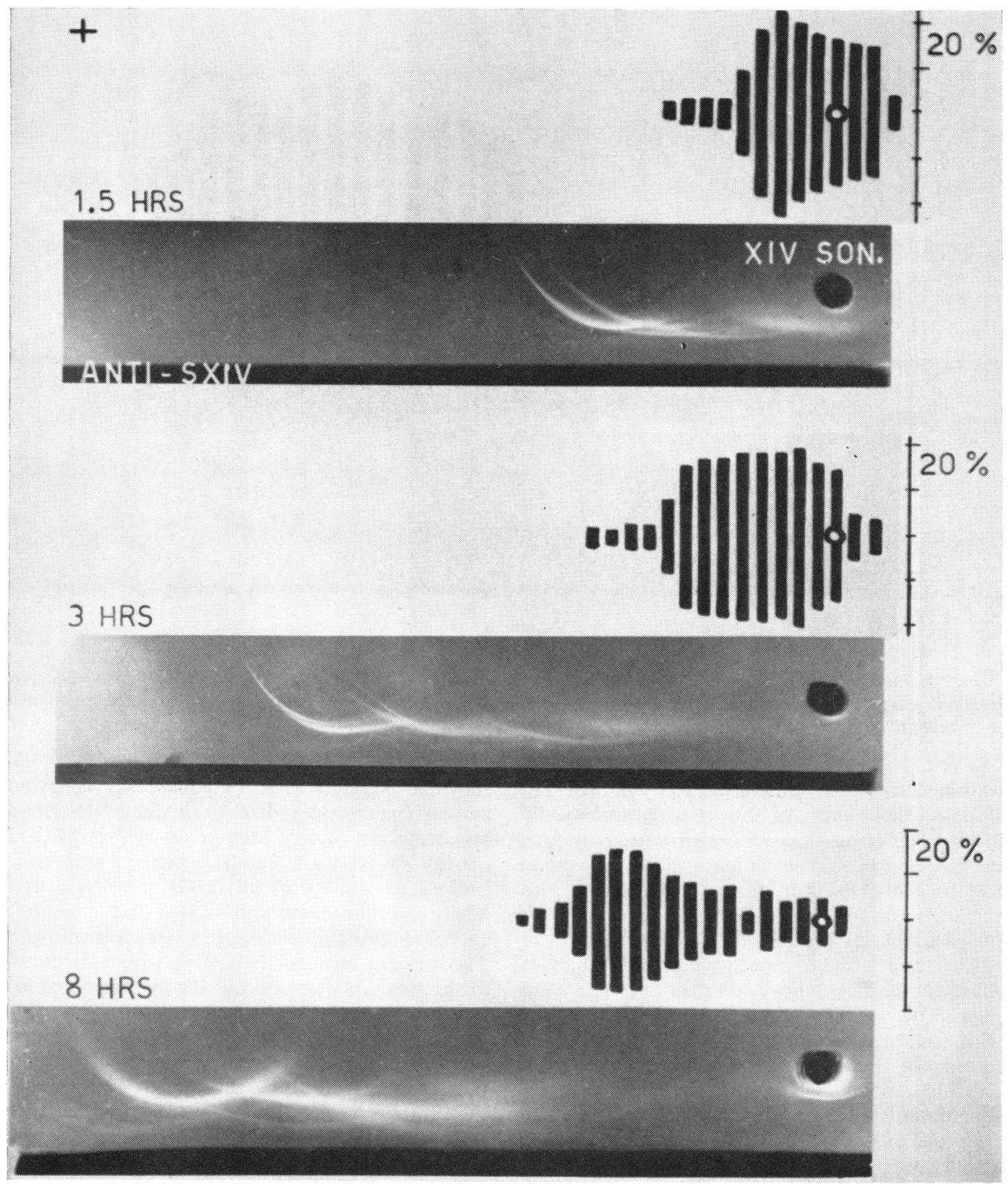

Fig. 3. Immunoelectrophoretic analysis of cell-free extract of a rough strain of pneumococcus (originally type $X I V)$ developed with anti-XIV. Electrophoretic mobility of neuraminidase is represented diagrammatically by results of enzyme assay performed after elution from agar sections of uniform size, cut along the path of migration. The enzyme value for each section is represented in its original position and in proportion to a scale in which each division equals $20 \%$ of the total acid-hydrolyzable NANA present in the substrate.

trough at one side of one sample, and was also layered over the area into which antigens from the other sample had migrated. This can be seen in Fig. 5, in which two lines of specific precipitate appeared as before (lower photograph), and, in the upper photograph, as an area of precipitate corresponding to the migrated antigen. This portion of the agar, after full development and 


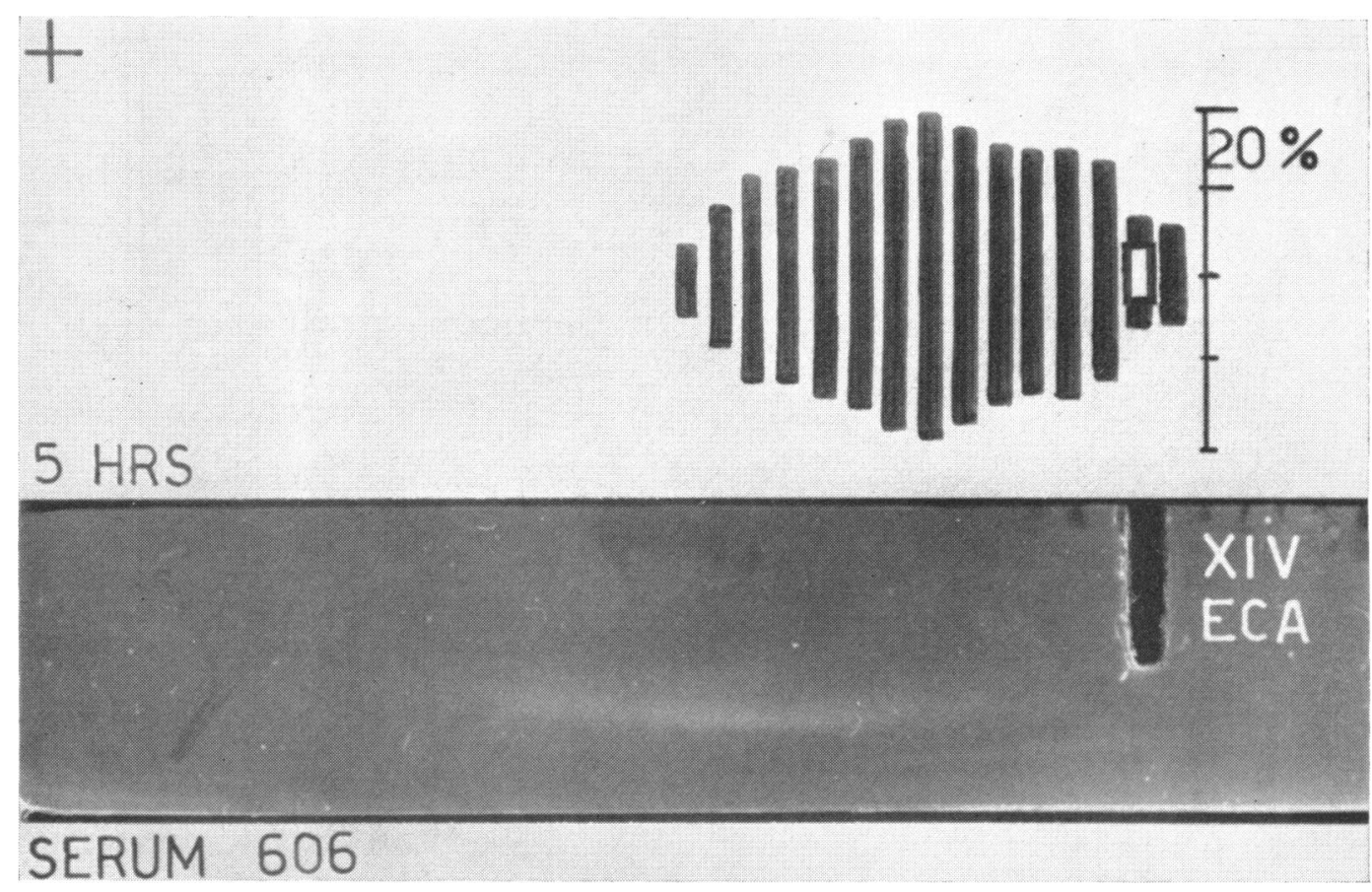

FIG. 4. Immunoelectrophoretic analysis of extracellular antigen (ECA) from rough strain of pneumococcus (originally type XIV) developed with anti-ECA (serum 606). Electrophoretic mobility of neuraminidase shown diagrammatically, as in Fig. 3.

washing in saline, was then analyzed for enzyme as described. As shown diagrammatically in the center of Fig. 5, enzyme activity was present in the area in which specific precipitate had formed. However, the enzyme activity also extended toward the cathode, beyond the area of specific precipitation.

The results of quantitative precipitin analyses ruled out the possibility that either of the antigens might be neuraminidase, which precipitated with, but was not neutralized by, antibody in serum 606. From Fig. 6 it can be seen that increasing amounts of enzyme were found in the supernatant fluids, corresponding with the increments of antigen added, and that no enzyme activity was found in the washed specific precipitates. It could be concluded, therefore, that neither of the two antigens revealed by immunoelectrophoretic analyses of ECA with anti-ECA (606) was neuraminidase, and that serum 606 contained neither precipitating nor neutralizing antienzyme.

Neutralization of neuraminidase in cell-free extract by type-specific antisera. The results of enzyme neutralization titrations of type-specific pneumococcal antisera with cell-free extracts are shown in Table 1. The end point in all instances was taken as the reciprocal of the serum dilution showing $50 \%$ or greater reduction in enzyme activity, when assayed in the manner described in Materials and Methods. Neuraminidase activity in all three cell-free extracts was neutralized to high titer with both homotypic and heterotypic antisera, indicating that pneumococcal neuraminidase is a group-specific antigen. The antisera referred to here had been prepared in rabbits and horses by the intravenous injection of whole killed pneumococci and contained, in addition to antineuraminidase, high titers of antibody to both type-specific capsular polysaccharide and $\mathrm{C}$ substance. Enzyme activity in ECA was also neutralized to high titer with anti-XIV (Fig. 7). No precipitate was formed, however, either in double diffusion with ECA and anti-XIV, or in immunoelectrophoretic analysis of ECA developed with anti-XIV.

A sample of type XIV antiserum was mixed with an equal volume of washed, packed type XIV pneumococcal cells. After incubation at $37 \mathrm{C}$ for $1 \mathrm{hr}$, overnight refrigeration, and centrifugation, the supernatant serum was again similarly absorbed and then tested for enzyme neutralization. The titer of antienzyme was undiminished (Fig. 7), although most of the antibody precipitating with other protein antigens had been removed by the two absorptions (Fig. 

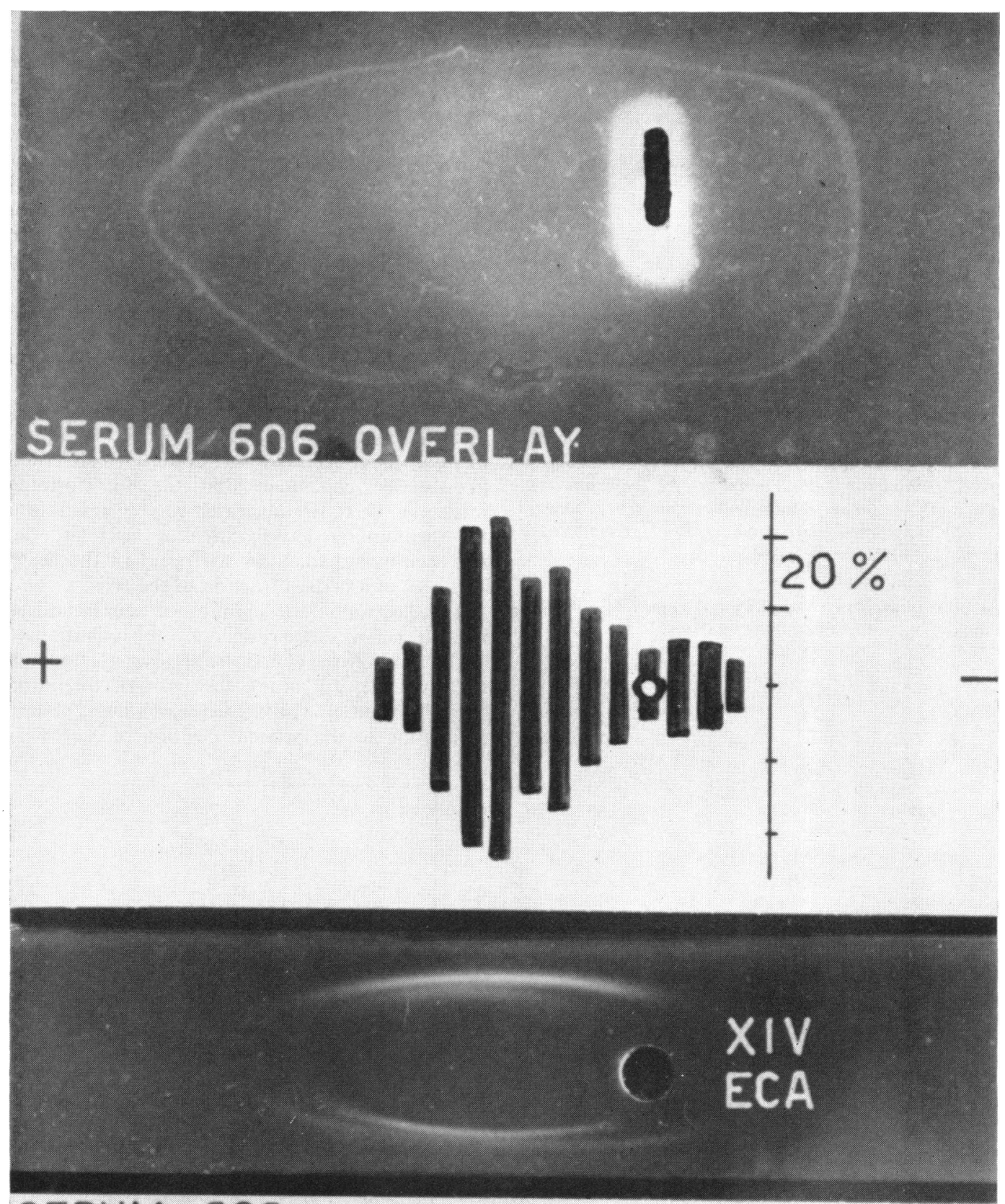

\section{SERUM 606}

FIG. 5. "Direct" immunoelectrophoretic analysis of extracellular antigen (ECA). Upper photograph: agar plate overlaid with anti-ECA (serum 606) after electrophoretic separation. Lower photograph: immunoelectrophoretic analysis developed with the same serum. Electrophoretic mobility of neuraminidase represented diagrammatically in center, as in Fig. 3 and 4.

8). Moreover, the bacterial cells used for absorption, while washed and packed in formalinized saline, still retained considerable neuraminidase activity. Two absorptions of the same serum with ECA likewise failed to reduce the neutralization titer (Fig. 7). The presence of nonprecipitating neutralizing antibody in the anti-XIV serum was therefore suggested by 


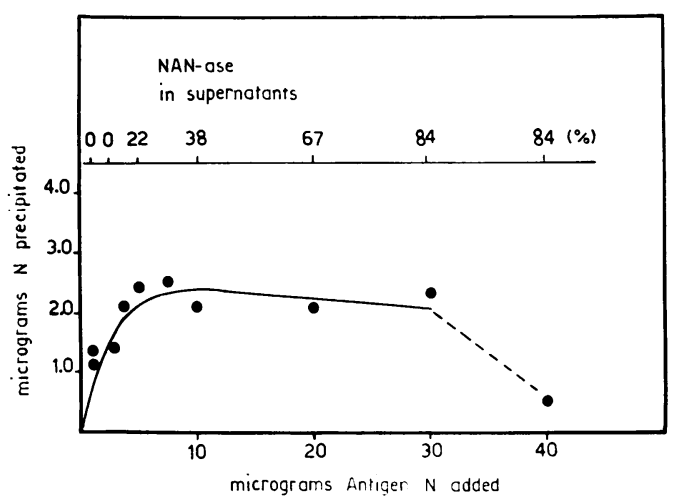

FIG. 6. Precipitin curve of serum 606 and ECA, showing failure to precipitate enzyme activity with homologous antibody. Microprecipitin method (4),

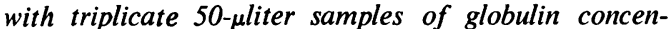
trated from serum 606. Precipitate for duplicate samples analyzed for nitrogen by microninhydrin procedure (9). No enzyme activity detected in precipitate of third sample at each point.

TABLE 1. Neutralization by antiserum of enzyme in cell-free extracts

\begin{tabular}{c|c|c}
\hline $\begin{array}{c}\text { Type from which } \\
\text { extract was derived }\end{array}$ & Antiserum & $\begin{array}{c}\text { Dilution of serum giving } \\
50 \% \text { or greater reduction } \\
\text { in enzyme activity }\end{array}$ \\
\hline III & III & 320 \\
& VII & 320 \\
VII & VII & 2,560 \\
XIV & XIV & 320 \\
& III & 320 \\
& VII & 2,560 \\
\hline
\end{tabular}

these findings, and by the results of "direct immunoelectrophoretic analysis," carried out as described above in connection with anti-ECA serum (606). After anti-XIV had been layered over the area of migration of ECA, no activity was detected at any point in the agar within the area corresponding to the distribution of active enzyme in control samples run in an identical manner.

\section{Discussion}

The data presented show that neuraminidase was secreted into the culture medium early in the exponential-growth phase of pneumococcus types I and XIV, and that the increase in enzyme activity paralleled that of the viable cells during the first 6 to $8 \mathrm{hr}$ after inoculation. The conditions for growth of the organism were optimal. Capsular polysaccharide and $\mathrm{C}$ substance did not appear in the medium in detectable quantities until the maximal viable-cell count and neuraminidase activity had been reached. This sequence of events suggests strongly that neuraminidase was actively excreted or lost from dividing cells well before much autolysis had occurred. The latter process supervened at about $8 \mathrm{hr}$, coinciding with the end of the logarithmic phase of growth, and explained the subsequent presence of cell wall and capsular polysaccharides in the culture fluid. Autolysis might also have accounted for a certain proportion of the total enzyme activity found after $8 \mathrm{hr}$, when active cell division had probably diminished. These conclusions are consistent with analogous observations of transforming principle (8), which was found also to be produced relatively early, i.e., in the logarithmic phase of growth, in pneumococcal cultures maintained under favorable conditions. It could likewise be concluded that the transforming principle, deoxyribonucleate, was secreted into the medium by actively dividing cells and did not accumulate solely as the result of the death and lysis of a certain fraction of the cells.

The electrophoretic mobility of neuraminidase in agar gel was determined by the quantitative assay of enzyme eluted from agar sections of uniform size, cut along the path of migration (Fig. 3, 4, and 5). The aggregate of values, plotted in relation to the original position of each agar

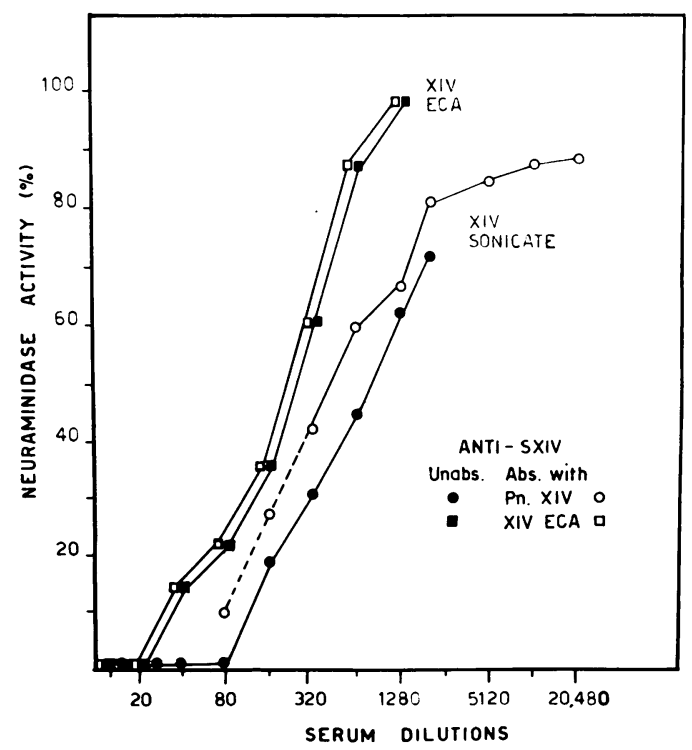

FIG. 7. Neutralization of type XIV sonic-treated material and ECA with unabsorbed and absorbed anti$X I V$ serum. Dotted line represents values corrected for enzyme activity added in absorbing antigen (formalinized pneumococcal cells). 


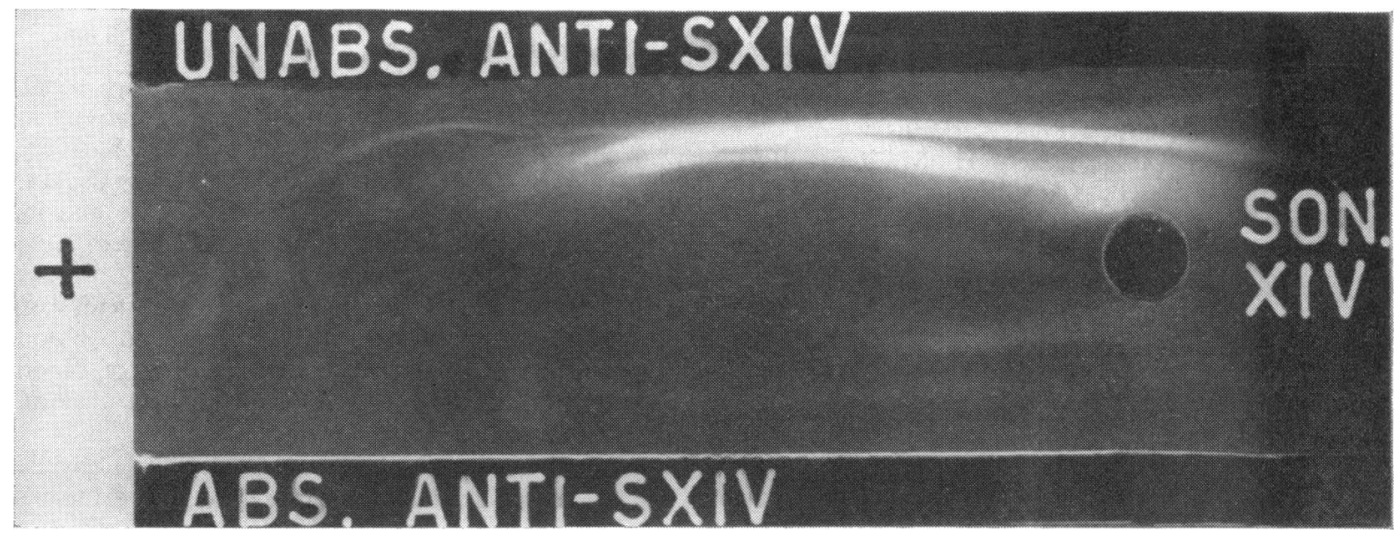

FIG. 8. Immunoelectrophoretic analysis of cell-free extract with anti-XIV, before and after absorption with formalinized suspension of pneumococcus, rough strain (originally type XIV).

slice, allowed an estimate of the mobility of the enzyme in each case. As found in the cell-free extract of rough pneumococci, the enzyme was slower in mobility than the several proteins revealed by precipitation with antibody (Fig. 3). This relatively wide separation under these conditions is consistent with the reported behavior of pneumococcal neuraminidase in relation to other proteins of the pneumococcus when applied to carboxymethylcellulose columns (3).

Our observations have substantiated the fact, implicit in the work of others, that neuraminidase is a group-specific antigen of the pneumococcus. Although at least two reports on pneumococcal neuraminidase have been concerned with enzymes of type I pneumococcus $(3,7)$, it was found in the present investigation that a type XIV strain and the rough strain derived from it were equally good sources of enzyme. Moreover, enzyme in cell-free extracts from two other types (III and VII) was neutralized by heterologous antisera, all of which also neutralized the enzyme from type XIV. The best antienzyme serum used in the present study, i.e., anti-XIV, failed to neutralize the neuraminidase of influenza virus (A2). This result is in accord with the observations of Madoff et al. (7), who found no serological crossing between neuraminidase from unrelated microorganisms, namely, Vibrio cholerae, pneumococcus, and influenza virus.

The partially purified ECA, derived from 12-hr culture fluid and containing neuraminidase, failed to elicit neutralizing antibody in rabbits when given in complete Freund adjuvant by the foot-pad route. However, antibodies to at least two other antigens, unrelated to neuraminidase, were produced (Fig. 4 and 5). Although these data are insufficient to allow more definitive conclusions, they at least suggest that neuraminidase in pneumococcal culture supernatant fluid may not be antigenic under these conditions. In contrast, antisera produced by injection of whole killed organisms into rabbits (anti-XIV) or horses (anti-I, -III, -VII) by the intravenous route, showed high neutralizing titers for neuraminidase in both cell-free extracts and ECA. This complex relationship of antigenicity to physical state of antigen and route of immunization is well known in connection with typespecific capsular polysaccharide. Antibody to pneumococcal polysaccharide is elicited in rabbits only in response to intravenous injection of whole organisms and slightly, if at all, by the subcutaneous or intramuscular inoculation of organisms, or the soluble substances, in complete Freund adjuvant. These observed differences still require explanation. The failure of pneumococcal neuraminidase to precipitate with neutralizing antibody, taken together with its apparent lack of antigenicity under conditions favorable for the production of precipitating antibody to other pneumococcal proteins, suggests that this particular enzyme may be of unusually small molecular weight. By way of comparison, the neuraminidase of $V$. cholerae, though serologically unrelated to the corresponding pneumococcal enzyme (7), has also been supposed, on better evidence, to be of very small molecular weight, perhaps less than 10,000 (9).

\section{ACKNOWLEDGMENTS}

This investigation was supported by Public Health Service grant AI-03168 and a General Research Grant from the National Institute of Allergy and Infectious Diseases. 


\section{Literature Cited}

1. Grabar, P., AND P. Burtin. 1964. Immunoelectrophoretic analysis. Elsevier Publishing Co., Amsterdam, The Netherlands.

2. Howe, C., L. T. LeE, AND H. M. Rose. 1961. Collocalia mucoid: a substrate for myxovirus neuraminidase. Arch. Biochem. Biophys. 95: 512-520.

3. Hughes, R. C., AND R. W. Jeanloz. 1964. The extracellular glycosidases of Diplococcus pneumoniae. Biochemistry 3:1535-1542.

4. KABAT, E. A., AND M. M. MAYER. 1961. Experimental immunochemistry, 2nd ed., p. 22. Charles C Thomas, Publisher, Springfield, Ill.

5. Kabat, E. A., AND G. Schiffman. 1962. Immunochemical studies on blood groups. XXVIII Further studies on the oligosaccharide determinants of blood group B and BP1 specificity. J. Immunol. 88:782-787.

6. Keller, S., AND I. MANDL. 1963. The preparation of purified collagenase. Arch. Biochem. Biophys. 101:81-87.

7. Madoff, M. A., E. H. Eylar, and L. WeinSTEIN. 1960. Serologic studies of the neuraminidases of Vibrio cholerae, Diplococcus pneu- moniae and influenza virus. J. Immunol. 85:603-613.

8. OtTolenghi, E., AND R. D. Hotchiss. 1960 Appearance of genetic transforming activity in pneumococcal cultures. Science 132:1257-1258.

9. Rosenberg, A., B. Binnie, and E. Chargaff. 1960. Properties of a purified sialidase and its action on brain mucolipid. J. Am. Chem. Soc. 82:4113-4114.

10. Schiffman, G., E. A. Kabat, AND W. Thompson. 1962. Immunochemical studies on blood groups. XXVII. Periodate oxidation of blood group $\mathbf{A}, \mathbf{B}$ and $\mathbf{O}(\mathbf{H})$ substances. J. Am. Chem. Soc. 84:463-467.

11. Uriel, J., AND P. Grabar. 1961. Une nouvelle réaction de caractérisation des glycoprotéines et des polysaccharides après électrophorèse ou immunoélectrophorèse en gélose, p. 195-198. In $\mathbf{H}$. Peeters [ed.], Protides of the biological fluids, Proc. 8th Colloq. Bruges, 1960. Elsevier Publishing Co., Amsterdam, The Netherlands.

12. WARren, L. 1959. The thiobarbituric acid assay of sialic acids. J. Biol. Chem. 234:1971-1975.

13. WiLsON, A. 1964. Direct immunoelectrophoresis. J. Immunol. 92:431-434. 